Volume 2 Nomor 2, Desember 2019

E-ISSN : 2655-7347

\title{
PERLINDUNGAN HUKUM TERHADAP KONSUMEN AKIBAT DUGAAN MANIPULASI IKLAN PELAKU USAHA BERDASARKAN UNDANG-UNDANG NOMOR 8 TAHUN 1999 TENTANG PERLINDUNGAN KONSUMEN
}

\author{
Zakaria Rasyid \\ (Mahasiswa Program S1 Fakultas Hukum Universitas Tarumanagara) \\ (E-mail: zakariarasyid@ gmail.com)
}

\begin{abstract}
Ermanto Fahamsyah
(Corresponding Author)

(Dosen Fakultas Hukum Universitas Tarumanagara. Meraih Sarjana Hukum pada Fakultas Hukum Universitas Jember. Magister Hukum Ekonomi pada Fakultas Hukum Universitas Indonesia.

Doktor (Dr) pada Fakultas Hukum Universitas Indonesia)
\end{abstract}

\begin{abstract}
This study aims to find out and analyze consumer protection. Manipulating advertisements carried out by companies based on Law Number 8 of 1999 Concerning Consumer Protection (case study of sweetened condensed milk). The research method in the discussion of this Thesis is normative research, that is research conducted to study the legal forms against consumers which are suspected of being manipulation of advertisements carried out by business actors based on Law Number 8 of 1999 Concerning Consumer Protection. Related to the issues discussed in this study concerning legal protection to consumers, the alleged manipulation of advertisements carried out by companies attempts based on Law No. 8 of 1999 concerning Consumer Protection.
\end{abstract}

Keywords: Protection, Consumer, Advertising, Sweetened Condensed Milk.

\section{PENDAHULUAN}

\section{A. Latar Belakang}

Seiring dengan berkembangnya zaman pada dunia industri, untuk menjaga kesehatan tubuh diperlukan asupan untuk menjaga tubuh tetap sehat dan kuat. Hal tersebut terlihat sangat wajar karena di era yang pada dengan berbagai aktivitas manusia dituntut untuk tetap tampil prima setiap harinya, maka itu diperlukan susu sebagai asupan nutrisi dan protein yang cukup bagi tubuh.

Perkembangan era perdagangan bebas yang terjadi pada saat ini membuat banyaknya produk yang diperdagangkan salah satunya susu, dari sekian banyak produk susu yang beredar di pasaran dengan berbagai jenis merek baik itu dalam bentuk bubuk maupun cairan kental. Untuk mempromosikan produk-produk susu tersebut, diperlukan suatu media iklan agar masyarakat khalayak banyak mengetahui jenis-jenis susu dan kegunaan serta kemanfaatan 
Volume 2 Nomor 2, Desember 2019

E-ISSN : 2655-7347

susu itu sendiri, karena pada zaman yang semakin maju pada saat ini kehadiran iklan sangat penting untuk perkembangan dan kemajuan para pelaku usaha.

Kedudukan iklan sangat penting bagi para pelaku usaha untuk mempromosikan produknya, karena jika tidak menggunakan iklan informasi ataupun distribusi produk tersebut tidak akan mengalir sampai konsumen ataupun pasar.

Seiring zaman yang semakin modern dengan berbagai kreatifitas dalam pembuatan iklan yang ditampilkan, sering kali ditemukan iklan-iklan yang menipu konsumen dengan visualisasi yang sedimikian rupa agar konsumen tertarik dengan produk-produk tersebut, keinginan setiap manusia untuk tetap tampil prima ternyata dimanfaatkan oleh para pelaku usaha dengan menampilkan iklan-iklan yang bersifat manipulatif agar dapat menarik perhatian para konsumen, karena iklannya yang menarik dan harganya yang relative terjangkau membuat konsumen tertarik untuk mengkonsumsi produk tersebut. Ketidaktahuan konsumen terhadap efek samping yang dakan ditimbulkan dari produk tersebut dijadikan suatu alasan mengapa konsumen tetap mengkonsumsi produk tersebut. Kebiasaan besar konsumen yang tidak teliti dalam membeli suatu produk, adalah factor yang mempengaruhi produk tersebut laku keras di pasaran.

Permasalahan susu kental manis diawali oleh statement Kementrian Kesehatan yang menyatakan bahwa kandungan gula dan karbohidrat pada kental manis sangat tinggi dan rendah protein. Sebagai ilustrasi jika anak telah mengkonsumsi susu kental manis 2 kali dalam sehari, itu artinya konsumsi gulanya telah melawati batasan kebutuhan gula harian. Berdasarkan Peraturan Menter Kesehatan Nomor 63 Tahun 2015 Tentang Penetapan BatasanBatasan Konsumsi Gula, Natrium dan Lemak, maksimal konsumsi harian manusia adalah gula 50 gram, natrium 2.000 miligram dan lemak 67 gram, jika dikonsumsi melebihi batas harian yang telah ditentukan maka akan berisiko terrkena penyakit hipertensi, stroke, diabetes dan serangan jantung. Hasil dari penelusuran yang dilakukan oleh $C N N$ bahwa warga selama ini 
Volume 2 Nomor 2, Desember 2019

E-ISSN : 2655-7347

merasa tertipu dengan iklan susu kental manis, mereka mengira susu kental manis yang mereka konsumsi sebagai salah satu menu sarapan pagi merupakan susu yang aman dan bermanfaat bagi keluarga.

Karena kasus-kasus sejenis seperti ini semakin marak terjadi dan dalam rangka melindungi konsumen, terutama anak-anak. Badan Pengawas Obat dan Makanan (BPOM) melalui konferensi pers mengeluarkan surat edaran bernomor HK.06.5.51.511.05.18.2000 tahun 2018 tentang Label dan Iklan pada Produk Susu Kental dan Analognya (Kategori Pangan 01.3).

Surat edaran tersebut ditujukan untuk para produsen, importir, distributor produk Susu Kental dan Analognya (Kategori Pangan 01.3). Berdasarkan latar belakang di atas penulis tertarik untuk mendalami kasus tersebut dengan membuat ke bentuk Skripsi dengan judul yang telah dicantumkan.

Awal mula kasus susu kental manis terjadi setelah pernyataan Kementrian Kesehatan Republik Indonesia di dalam akun media sosialnya yang menyatakan bahwa kandungan gula dan kabohidrat yang terdapat dalam susu kental manis begitu tinggi dan rendah akan protein.

Hal tersebut akan berdampak buruk bagi konsumen khusunya anak-anak jika mengkonsumsi susu kental manis dalam skala yang berlebihan akan berdampak obesitas pada berat badan anak-anak. Iklan yang selama ini ditampilkan dalam susu kental manis ternyata kandungannya tidak sesuai dengan yang tercantum dalam iklannnya, sehingga masyarakat mendapatkan informasi yang tidak sesuai dengan produk susu kental manis.

Setelah ramai diperbincangkan oleh masyarakat luas terkait dengan susu kental manis, Badan Pengawas Obat dan Makanan (BPOM) mengeluarkan Surat Edaran bernomor HK.0.5.51.511.05.18.2000 Tentang Label dan Iklan Pada Produk Susu Kental Manis dan Analognya (Kategori Pangan 01.3). Surat Edaran tersebut berisi :

BPOM menegaskan, bahwa ada 4 poin penting dalam surat edaran terkait produk susu kental manis tersebut :

1. Iklan dan label dilarang menampilkan anak-anak usia balita

2. Tidak menyamakan susu kental manis dengan susu lainnya. 
Volume 2 Nomor 2, Desember 2019

E-ISSN : 2655-7347

3. Dilarang menvisuailisasikan gambar susu kental manis diseduh dan diminum didepan anak-anak.

4. Harus menyesuaikan produk dengan ketentuan BPOM yang telah diberitahukan.

Saat ini di Indonesia masih sering ditemukan iklan yang tidak sesuai dengan kegunaan dan kebenarannya salah satunya iklan susu kental manis. Dari berbagai merek susu kental manis semua iklan yang ditampilkan dalam televisi sampai media cetak selalu merepresentasikan orang tua dan anakanaknya mengkonsumsi susu kental manis sebagai asupan gizi dan protein yang sehat bagi anak-anaknya setiap harinya.

Padahal jika ditelaah lebih lanjut kedalam kandugan yang terdapat dalam susu kental manis yang mana di dalamnya mempunyai zat gizi dan prrotein yang tidak sesuai dengan ketentuan yang berlaku. Kadar gula yang cukup tinggi dan protein yang sedikit, jika dikonsumsi melebihi akan berdampak tidak baik untuk anak-anak dikemudian hari.

Keluarnya surat edaran Badan POM dalam rangka memberikan perlindungan hukum bagi konsumen dari iklan yang sesat. Namun sayangnya masyarakat menilai tindakan dari BPOM terbilang lambat, banyak iklan produk susu kental manis sejak dahulu kala yang menyebutkan bahwa susu kental manis adalah produk susu minuman yang bergizi dan berprotein tinggi yang bermanfaat bagi anak-anak. representasi iklan yang menjadikan anakanak sebagai tokoh utama dalam iklan susu kental manis tersebut disinyalir menjadi faktor utama yang membuat para orang tua masih memberikan susu kental manis sebagai asupan gizi dan protein untuk anak-anaknya.

Manipulasi iklan yang dilakukan oleh para pelaku usaha susu kental manis, merupakan salah satu bentuk yang bertentangan dengan beberapa peraturan yang telah ditetapkan dalam penyelenggaraan iklan yang baik dan benar serta dapat menjadi edukasi bagi masyarakat. Berikut ini adalah bahwa pelaku usaha susu kental manis melakukan manipulasi iklan yang melanggar aturan, yaitu: 
Volume 2 Nomor 2, Desember 2019

E-ISSN : 2655-7347

1. Tidak memberikan anjuran tentang kegunaan suatu poduk yang melanggar Pasal 54 Peraturan Badan Pengawas Obat dan Makanan Nomor 31 Tahun 2018 Tentang Label Pangan Olahan.

2. Menampilkan visualisasi iklan susu kental manis sebagai asupan gizi yang melanggar Pasal 67 huruf W Peraturan BPOM Nomor 31 Tahun 2018 Tentang Label Pangan Olahan.

3. Iklan memuat keterangan pangan secara tidak berurutan yang melanggar Pasal 19 ayat (1) PP No 69 Tahun 99.

4. Iklan memuat keterangan mengenai pangan yang tidak benar dan menyesatkan yang melanggar Pasal 44 PP No 69 thn 99.

5. Iklan menampilkan anak-anak sebagai pengajur penggunaan suatu produk yang kegunaannya bukan untuk anak-anak yang tidak sesuai dengan Etika Pariwara Point 3.1.3.

6. Iklan yang ditampilkan memiliki sifat yang mengelabui konsumen mengenai kualitas suatu barang dan/atau jasa yang melanggar Pasal 17 ayat (1) huruf a UUPK.

7. Tidak menjamin mutu barang dan/atau jasa sesuai ketentuan yang berlaku diatur Pasal 7 UUPK.

8. Menampilkan visualisasi iklan SKM yang persis dengan susu murni yang melanggar Pasal 3 ayat (2) PERKA BPOM No 2 Tahun 2016

9. Menampilkan Balita yang bertentangan dengan Pasal 5 Peraturan Kepala BPOM Nomor 2 Tahun 2016.

Dari alasan-alasan tersebut, manipulasi iklan yang dilakukan oleh pelaku usaha susu kental manis juga melanggar beberapa peraturan terkait, berirkut ialah peraturan terkait dengan manipulasi iklan susu kental manis:

1. Manipulasi iklan susu kental manis melanggar Pasal 4 UUPK.

2. Manipulasi iklan susu kental manis melanggar Pasal 8 UUPK.

3. Manipulasi iklan susu kental manis melanggar Pasal 10 UUPK.

4. Manipulasi iklan susu kental manis melanggar Pasal 17 UUPK.

5. Manipulasi iklan susu kental manis melanggar Pasal 54 Per BPOM No 31 Tahun 2018. 
Volume 2 Nomor 2, Desember 2019

E-ISSN : 2655-7347

6. Manipulasi iklan susu kental manis melanggar Pasal 19 ayat (1) PP Nomor 69 Tahun 1999 tentang Label dan Iklan Pangan.

7. Manipulasi iklan susu kental manis melanggar Pasal 44 PP Nomor 9 Tahun 1999.

8. Manipulasi iklan susu kental manis melanggar Etika Pariwara Periklanan Point 3.1.3

9. Manipulasi iklan susu kental manis melanggar Pasal 3 ayat (2) PER KA Badan POM No 2 Thn 2016.

10. Manipulasi iklan susu kental manis melanggar Pasal 5 PER KA Badan POM No 2 Thn 2016.

Upaya dalam memberikan perlindungan hukum kepada konsumen, tindakan Badan Pengawas Obat dan Makanan hanya dapat memberikan suatu sanksi administratif setelah terbukti melanggar PERKA BPOM Nomor 2 Tahun 2016 Tentang PTP3O, menurut BPOM sanksi administratif yang diberikan dapat menimbulkan efek jera kepada pelaku usaha dikarenakan mereka tidak dapat berdagang sampai adanya perbaikan terhadap produk susu kental manis, terkait dengan tuntutan ganti rugi kepada pelaku usaha BPOM tidak bisa mengintervensi lebih lanjut. Selama ini konsumen hanya memberikan suatu aduan terhadap produk susu kental manis ke BPOM tetapi dari aduan tersebut tidak ada yang berujung sampai ke pengadilan.

Susu kental manis menurut BPOM sebenarnya mengandung susu bukan hanya gula, tetapi mengapa susu kental manis itu dilarang dikarenakan mereka iklannya mengelabui konsumen dengan dalil bahwa susu kental manis berguna bagi perkembangan tubuh anak, sehingga para orang tua memberikan susu kental manis sebagai asupan gizi yang cukup bagi anaknya menurut BPOM iklan tersebut sudah memasuki ranah pembohongan publik.

Badan Pengawas Obat dan Makanan juga telah melakukan upaya-upaya dalam hal memberikan perlindungan hukum yang maksimal kepada konsumen terhadap produk susu kental manis yang beredar di masyarakat 
Volume 2 Nomor 2, Desember 2019

E-ISSN : 2655-7347

dengan melarang seluruh pelaku usaha untuk memproduksi iklan yang menyesatkan dan tidak sesuai dengan ketentuan yang telah diatur oleh BPOM, iklan yang diawasi tidak hanya iklan yang berada dalam media elektronik saja tetapi mengcakup iklan pada media cetak. BPOM pun juga terjun langsung ke para pelaku usaha agar segera memperbaiki produknya dengan standar ketentuan yang sudah diatur dalam peraturan BPOM. Untuk pengawasan terhadap iklan susu kental manis agar tidak kembali ditayangkan BPOM bekerja sama dengan Komisi Penyiaran Indonesia (KPI) agar masalah iklan susu kental manis dapat teratasi sehingga para konsumen agar tidak khawatir terhadap produk tersebut.

\section{B. Permasalahan}

Berdasarkan uraian latar belakang diatas, maka permasalahannya ialah: Bagaimana Perlindungan Hukum Terhadap Konsumen Akibat Dugaan Manipulasi Iklan Pelaku Usaha Berdasarkan Undang-Undang Nomor 8 Tahun 1999 tentang Perlindungan Konsumen?

\section{C .Metode Penelitian}

Menurut Parsons penelitian adalah pencarian atas sesuatu secara sistematis dengan penekanan bahwa pencarian ini dilakukan terhadap masalah-masalah yang dapat dipecahkan. ${ }^{1)}$ Penelitian hukum merupakan suatu hal yang terdapat dalam ilmu hukum untuk dapat mencari solusi atas suatu permasalahan serta memperoleh kebenaran terhadap suatu hal yang tidak dilakukan sebagaimanamestinya atau seharusnya. ${ }^{2)}$ Sehingga metode penelitian hukum adalah hal yang didasarkan pada suatu metode, serta pemikiran tertentu dengan tujuan untuk mencari solusi atas permasalahan agar diketahui hal apa yang seharusnya dilakukan.

\footnotetext{
1) Moh. Nazir, “Metode Penelitian”. (Bogor: Ghalia Indonesia, 2005), hal. 12-13.

2) Peter Mahmud, Penelitian Hukum, Cetakan ke-7. (Jakarta: Kencana Prenada Media Group, 2016), hal. 59-69.
} 
Volume 2 Nomor 2, Desember 2019

E-ISSN : 2655-7347

Metode penelitian yang digunakan oleh penulis adalah metode penelitian hukum normatif. Metode pengumpulan bahan-bahan hukum adalah sebagai berikut:

1. Jenis Penelitian

Jenis penelitian yang digunakan dalam penelitian ini adalah penelitian hukum normatif. Penelitian hukum merupakan suatu proses untuk menemukan aturan hukum, prinsip hukum, maupun doktrin untuk dapat menjawab permasalahan yang dihadapi.

2. Sifat Penelitian

Sifat penelitian yang dipakai dalam penelitian ini ialah penelitian dengan sifat yang normatif, praktis dan preskriptif. ${ }^{3)}$

3. Jenis dan Teknik Pengumpulan Bahan Hukum

a. Bahan Hukum Sekunder

Bahan hukum sekunder yang digunakan dalam penulisan ini terdiri dari: literatur yang berkaitan dengan perlindungan konsumen, bukubuku yang berkaitan dengan perlindungan konsumen, hasil penelitian ilmiah yang berkaitan dengan permasalahan, majalah/jurnal hukum yang sesuai dengan permasalahan, serta bahan-bahan lain yang mengikuti kasus.

b. Bahan NonHukum

Bahan nonhukum adalah bahan diluar bahasan hukum yang merupakan bahan hukum yang memberikan petunjuk ataupun penjelasan terhadap bahan hukum primer maupun sekunder. ${ }^{4)}$ Selain itu juga berguna untuk memperluas wawasan, serta memberikan penjelasan untuk menyelesaikan permasalahan yang ada. ${ }^{5)}$

\footnotetext{
3) Philipus M. Hadjon dan Tatiek Sri Djamiati, Argumentasi Hukum. (Yogyakarta: Gadjah Mada University Press, 2005), hal. 1.

4) Bambang Sunggono. Metodologi Penelitian Hukum. (Jakarta: Raja Grafindo Persada, 1996).

5) Peter Mahmud, Op. Cit., hal 184.
} 
Volume 2 Nomor 2, Desember 2019

E-ISSN : 2655-7347

4. Pendekatan Penelitian

Metode pendekatan penelitian yang digunakan dalam penelitian ini adalah pendekatan kasus (case approach) dan pendekatan perundangundangan( statute approach). Metode ini dipilih karena dianggap merupakan metode yang paling sesuai untuk dapat menjawab permasalahan dalam penulisan ini, yang mengkaji tentang Perlindungan Hukum Terhadap Konsumen Akibat Manipulasi Iklan Pelaku Usaha Berdasarkan Undang-Undang Nomor 8 Tahun 1999 tentang Perlindungan Konsumen.

\section{Teknik Analisis Bahan Hukum}

Teknik analisis dalam penelitian ini menggunakan teknik analisis bahan hukum dengan cara logika deduktif atau pengolahan bahan hukum dengan cara deduktif, yaitu menjelaskan suatu hal yang bersifat umum kemudian menariknya menjadi kesimpulan yang lebih khusus.

\section{PEMBAHASAN}

\section{A. Perlindungan Hukum Terhadap Konsumen Akibat Dugaan Manipulasi}

\section{Iklan Pelaku Usaha Berdasarkan Undang-Undang Nomor 8 Tahun 1999}

\section{Tentang Perlindungan Konsumen}

Perlindungan konsumen di dalam pasal 1 angka 1 Undang-Undang Nomor 8 Tahun 1999 tentang Perlindungan Konsumen dikatakan bahwa "segala upaya yang menjamin adanya kepastian hukum untuk memberi perlindungan kepada konsumen.

Berbicara tentang konsumen, tak luput juga tentang perlindungan hukum dan perlindungan konsumen di Indonesia kedua hal tersebut masih harus diperjuangkan dan diperbaikin meskipun masih ada kendala dalam praktiknya. Karena baik dari sisi aturan, pengawasan lembaga dan pelaku usaha masih belum menjalankan fungsi dan kewajibannya masing-masing. Menurutnya terdapat beberapa penyebab perlindungan konsumen tidak dapat berjalan maksimal, yaitu : 
Volume 2 Nomor 2, Desember 2019

E-ISSN : 2655-7347

a. Regulasi yang tidak cukup atau regulasi yang tumpang-tindih. Selain itu sumber daya manusia di Badan Penyelesaian Sengketa Konsumen kurang maksimal, karena sering kali ditemukan putusan yang tidak sesuai aturan.

b. lembaga tidak hanya dari pemerintah ataupun lembaga swadaya lainnya.

c. konsumen di Indonesia masih jauh dibawah harapan dari Index Kecerdasan Konsumen, yang mana di Indonesia tidak sampai 30\% jauh dari kata ideal index tersebut.

Terkait dengan iklan susu kental manis, menurutnya ada 3 pihak yang terkait :

a. produsen adalah pelaku usaha yang memproduksi Susu Kental Manis, agar barang produksinya dapat dikenal dan digunakan oleh masyarakat, pelaku usaha menggunakan metode promosi berupa iklan.

b. pelaku usaha periklanan adalah perusahaan yang menjual jasa periklanan untuk hal ini pelaku usaha memerlukan keahlian pelaku usaha periklanan dalam membuat iklan tentang produk pelaku usaha.

c. Badan POM, sebagai regulator dalam pengawasan dan peredaran obat dan makanan di negeri ini, BPOM mempunyai andil penting terkait dalam susu kental manis yang dalam iklannya bersifat manipulatif.

Ketiga pihak tersebut adalah pihak yang memiliki peran yang besar terkait susu kental manis yang beredar di masyarakat, jika di telaah lebih jauh susu kental manis sebenarnya bukan susu yang bermanfaat bagi tubuh, ahli gizi dari Jerman yaitu Prof. Weigmann sudah memperingatkan kurangnya manfaat susu kental manis bagi tubuh dan iklan yang tercantum dalam label susu kental manis tidak sesuai dengan kandungan yang sesungguhnya, padahal negara yang mencetus lahirnya susu kental manis tidak menyarankan penggunaan susu kental manis sebagai asupan gizi dan protein bagi tubuh khususnya anak-anak.

Rendahnya index kecerdasan konsumen merupakan faktor mengapa masyarakat Indonesia masih saja menggemari produk-produk yang rendah akan manfaat seperti susu kental manis ini dengan iklan yang menggambarkan keluarga 
Volume 2 Nomor 2, Desember 2019

E-ISSN : 2655-7347

lengkap dengan anak-anaknya mengkonsumsi susu kental manis sebagai asupan gizi dan proteinnya. Masyarakat Indonesia selalu terpikat dengan hal-hal yang menurutnya menarik bukan melihat atas manfaatnya produk tersebut, maka dari itu penipuan-penipuan terhadap konsumen masif digunakan dan masih sering terjadi hingga saat ini.

Berbicara mengenai suatu produk maka tak lepas peran dari konsumen sebagai pengguna produk tersebut, dalam kasus susu kental manis, pada umumnya masyarakat beranggapan bahwa susu kental manis yang mereka ketahui selama ini sangat aman dan bermanfaat jika dikonsumsi oleh anak-anak sebagai asupan gizi dan tumbuh kembang anak. Oleh karena itu beliau masih menggunakan produk susu kental manis sebagai asupan pendamping untuk kebutuhan sarapan setiap harinya, ketika penulis bertanya mengenai yang menjadi faktor beliau membeli produk susu kental manis, menurutnya ada beberapa faktor sebagai berikut:

1. Iklan, konsumen menilai iklan yang ditampilkan produk susu kental manis yang menampilkan anak-anak mengonsumsi susu kental manis sebagai sarapan sebelum memulai aktifitasnya, menjadi faktor mengapa konsumen memberikan susu kental manis sebagai asupan gizi dan tumbuh kembang bagi anak-anaknya. Menurutnya karena iklan yang ditampilkan susu kental manis, membuat mereka mengira SKM memiliki kegunaan yang setimpal dengan susu lainnya.

2. Label "susu", menurut konsumen label susu pada produk susu kental manis yang membuat anggapan mereka bahwa susu kental manis benar-benar seperti susu lain pada umumnya. Karena persepsi mereka bahwa kata susu dan kandungan yang terdapat dalam susu kental manis sama akan manfaatnya dengan susu lainnya.

3. Rasa yang terkandung dalam susu kental manis yang manis dan tidak bau amis sangat digemari oleh anak-anak. menurutnya anak-anak sangat menyukai susu kental manis karena rasanya lebih enak ketimbang susu bubuk.

4. Harga yang murah dan mudah ditemui dimana saja merupakan salah satu faktor mengapa susu kental manis sangat laku keras dalam pasaran, masalah 
Volume 2 Nomor 2, Desember 2019

E-ISSN : 2655-7347

ekonomi menjadi faktor yang penting, jika susu kental manis dengan harga yang murah memiliki manfaat yang sama dengan susu murni lainnya.

5. Faktor-faktor tersebut menjadi penyebab persepsi yang baik masyarakat kepada produk susu kental manis. Padahal kenyataannya iklan dan kandungan yang terdapat dalam susu kental manis merupaka hal yang tidak benar, oleh karena itu beliau meminta kepada pemerintah agar menindak para pelaku usaha susu kental manis dengan tegas agar terkait dengan kasus ini tidak terjadi lagi dikemudian hari.

Ketika ditanya tentang surat edaran yang dikeluarkan oleh BPOM terkait dengan kekisruhan SKM, beliau tidak mengetahui tentang informasi tersebut. Penulis menilai seharusnya Badan Pengawas Obat dan Makanan melakukan sosialisasi lebih detail dan mengedukasi kepada masyarakat secara langsung agar tidak ada masyarakat yang tertipu dan tetap menggunakan susu kental manis kepada anatuk-anaknya sebagai asupan gizi, protein dan tumbuh kembang anak.

Pelaku usaha dalam melakukan promosi terhadap produknya melalui media elektronik dan media cetak haruslah memberikan informasi data yang benar, jelas dan tidak menipu masyarakat. Mengiklankan produknya pelaku usaha sering tidak memperhatikan hal-hal yang telah diatur, karena sampai saat ini masih sering ditemukan adanya iklan yang visualisasinya tidak sesuai dengan kenyataannya dan sering memberikan informasi yang keliru dari iklan produk yang diperdangankan.

Badan Pengawas Obat dan Makanan juga telah melakukan upaya-upaya dalam hal memberikan perlindungan hukum yang maksimal kepada konsumen terhadap produk susu kental manis yang beredar di masyarakat dengan melarang seluruh pelaku usaha untuk memproduksi iklan yang menyesatkan dan tidak sesuai dengan ketentuan yang telah diatur oleh BPOM, iklan yang diawasi tidak hanya iklan yang berada dalam media elektronik saja tetapi mengcakup iklan pada media cetak. BPOM pun juga terjun langsung ke para pelaku usaha agar segera memperbaiki produknya dengan standar ketentuan yang sudah diatur dalam peraturan BPOM. Untuk pengawasan terhadap iklan susu kental manis agar tidak kembali ditayangkan 
Volume 2 Nomor 2, Desember 2019

E-ISSN : 2655-7347

BPOM bekerja sama dengan Komisi Penyiaran Indonesia (KPI) agar masalah

iklan susu kental manis dapat teratasi sehingga para konsumen agar tidak khawatir terhadap produk tersebut.

Hingga saat ini di Indonesia masih sering ditemukan iklan-iklan baik di televisi maupun media lainnya menanyangkan suatu produk yang tidak sesuai dengan kebenarannya, salah satu iklannya adalah Susu Kental Manis yang sering disebut dengan SKM. Produk Susu Kental Manis merupakan suatu produk yang tidak asing lagi dikalangan masyarakat Indonesia, baik untuk dikonsumsi pribadi maupun pelaku usaha yang berdagang menggunakan bahan Susu Kental Manis.

Seperti yang diketahui Susu Kental Manis hadir di Indonesia jauh sebelum negara ini mennyatakan kemerdekannya, iklan yang ditampilkanpun tidak jauh berbeda dengan yang ditampilkan pada saat ini. Ketidakbenaran dalam menyampaikan informasi tentang Susu Kental Manis yang mana dimuat didalam iklannya menyatakan bahwa Susu Kental Manis dapat berguna bagi gizi dan protein yang cukup bagi tubuh.

Representasi dari produk dan klaim manfaat yang ditampilkan dalam iklaniklan tersebut ternyata tidak sesuai dengan kenyataan kandungan yang tercantum pada produk susu kental manis. Dari hasil wawancara dengan BPOM menyatakan bahwa sebenarnya susu kental manis merupakan bentuk dari susu yang dicairkan dan di tambahkan gula sebagai bahan pendukungnya. Hanya saja kurangnya protein dan banyaknya kandungan gula pada susu kental manis jika dikonsumsi dalam jangka panjang dan berlebih akan memberikan dampak negatif bagi konsumen khususnya anak-anak apabila diminum secara rutin dan melebihi dosis harian. Dampak yang ditimbulkan tidak main-main karena dapat memicu terjadinya obesitas, diabetes dini dan berbagai penyakit lainnya. Kandungan gula yang ada dalam susu kental manis menimbulkan rasa ketagihan pada konsumen terlebih lagi susu kental manis dapat dijadikan sebagai bahan tambahan makanan maupun minuman.

Berdasarkan dari itu apabila iklan tidak memberikan suatu kebenaran terhadap produk tersebut kepada konsumen khususnya orang tua dapat menyalah artikan dan memberikan secara langsung dan bebas mebiarkan anak-anak mereka 
Volume 2 Nomor 2, Desember 2019

E-ISSN : 2655-7347

untuk mengonsumsi susu kental manis secara rutin dan berlebih. Setelah penulis melakukan wawancara dengan beberapa konsumen terkait dengan susu kental manis, ternyata masih ada keluarga yang menyatakan bahwa anak-anak mereka masih diberikan susu kental manis sebagai minuman ataupun sarapan paginya.

Iklan yang ditampilkan oleh produsen susu kental manis, membuat persepsi orang tua memahami bahwa susu kental manis dapat dijadikan sebagai pengganti susu murni, maka orang tua tidak pernah keberatan atau melarang anak-anak mereka mengonsumsi susu kental manis sebagai pemenuhan gizi dan protein hariannya.

Dilihat dari kandungan dari susu kental manis seharunya meninggalkan atau menghapus kata "susu" pada produk ataupun label kemasannya. Namun dikarenakan visualisasi iklan yang tetap menampilkan seakan-akan bahwa produk tersebut setara dengan susu lainnya, maka iklan-iklan menipu masyarakat.

Iklan ialah salah satu media promosi suatu produk barang atau jasa yang dilakukan oleh pelaku usaha, karena merupakan cara yang efektif untuk menarik minat konsumen, memberikan informasi produk dengan tujuan menawarkan produknya kepada konsumen. Iklan sebagai sarana promosi seharunya menyampaikan informasi tentang produk secara benar, jelas dan jujur sesuai undang-undang yang mengaturnya, karena tampilan dari iklan dapat mengubah pola pikir dan daya beli konsumen.

Berkaitan dalam menyampaikan iklannya para pelaku usaha harus memperhatikan kode etik beriklan yang terdapat dalam Etika Pariwara Indonesia (EPI). Etika Pariwara Indonesia adalah suatu kitab tentang tata krama dan tata cara periklanan yang dibuat oleh Dewan Periklanan Indonesia yang terdiri dari sebelah asosiasi atau lembaga yang terkait langsung dengan industri periklanan di Indonesia. Penyusunan dan penegakkan Etika Pariwara Indonesia ini dilakukan sejalan dengan prinsip-prinsip swakramawi (self-regulation) yang dianut oleh industri periklanan secara universal.

Iklan yang memanipulasi kepada masyarakat, yang mana informasi tersebut dapat menimbulkan kekeliruan ataupun kesalahpahaman kepada konsumen. Iklan tersebut sangat jelas melanggar Etika Pariwara Indonesia dan peraturan 
Volume 2 Nomor 2, Desember 2019

E-ISSN : 2655-7347

perundang-undangan yang terkait dengan periklanan. Konten iklan yang ditampilkan dalam susu kental manis yang di dalamnya terdapat ketidaksesuaian dari segi representasi ataupun ilustrasi secara audio visual dan klaim atas kemanfaatannya dengan kandungan yang sesungguhnya dalam susu kental manis, telah melanggar asas utama yang tercantum dalam Etika Pariwara Indonesia yang menyatakan bahwa iklan itu harus jujur, benar dan bertanggung jawab, manipulasi dari konten iklan yang ditampilkan oleh susu kental manis berakibat konsumen terkelabui, sehingga dapat dinilai bahwa iklan tersebut tidak jujur dan benar, yang menimbulkan kerugian bagi konsumen.

Kemudian apabila iklan yang ditampilkan menimbulkan kerugian bagi konsumen, maka ada peluang bagi konsumen untuk meminta pertanggung jawaban. Bentuk dari pertanggung jawaban tersebut merupakan suatu konsekuensi hukum yang lahir akibat iklan yang menyimpang dan melanggar dari ketentuan dan perundang-undangan yang berlaku.

Problematika yang hadir dan harus dipecahkan dalam meminta pertanggung jawaban pelaku usaha terkait dengan periklanan adalah bagaimana menentukan besaran tanggung jawab masing-masing pelaku usaha sesuai dengan peran serta partisipasinya dalam proses pembuatan hingga terbitnya iklan yang melanggar peraturan dan perundang-undangan tersebut. Tata cara untuk menentukan pertanggung jawaban atas iklan dapat dilakukan kepada pihak-pihak, yaitu :

1. Produsen, jika iklan yang ditayangkan atas permintaan dari produsen/pelaku usaha baik dari segi bentuk, ide produsen atau pelaku usaha memiliki tanggung jawab yang secara penuh.

2. Biro Iklan, membuat atau mendesai iklan tersebut beserta isinya, maka biro iklan bertanggung jawab atas iklan tersebut.

3. Media iklan, akan tetapi dalam penayangan iklan tersebut terdapat perbedaan dan perubahan dengan kondisi sebenarnya, maka media iklan bertanggung jawab atas iklan tersebut.

Maka dari itu pembebanan tanggung jawab atas hal tersebut jatuh kepada pihak yang memiliki peran paling besar dalam pembuatan iklan. Pada kenyataannya pembuatan suatu iklan berasal dari produsen atau pelaku usaha, 
Volume 2 Nomor 2, Desember 2019

E-ISSN : 2655-7347

karena umumnya pihak produsenlah yang memiliki ide tentang media apa yang digunakan untuk beriklan, siapa yang menjadi model iklannya dan bagaimana harusnya iklan tersebut ditampilkan sehingga dapat menarik minat konsumen untuk membeli produknya yang ditawarkan melalui media iklan yang dibuat tersebut. Semua aspek ini akan dituangkan pada sebuah proposal dari pembuat iklan kepada pemesan iklan. Setelah kedua pihak telah setuju, maka iklan tersebut akan diproduksi, dalam titik persetujuan inilah tanggung jawab terbesar terhadap munculnya iklan pada media elektronik ataupun cetak jatuh kepada pihak produsen, dalam hal ini konsekuensi hukum akan dibebankan kepada produsen pemilik produk.

Keluarnya surat edaran Badan POM dalam rangka memberikan perlindungan hukum bagi konsumen dari iklan yang sesat. Namun sayangnya masyarakat menilai tindakan dari BPOM terbilang lambat, banyak iklan produk susu kental manis sejak dahulu kala yang menyebutkan bahwa susu kental manis adalah produk susu minuman yang bergizi dan berprotein tinggi yang bermanfaat bagi anak-anak. representasi iklan yang menjadikan anak-anak sebagai tokoh utama dalam iklan susu kental manis tersebut disinyalir menjadi faktor utama yang membuat para orang tua masih memberikan susu kental manis sebagai asupan gizi dan protein untuk anak-anaknya untuk memenuhi kebutuhan sarapan sehari-harinya.

Manipulasi iklan yang dilakukan oleh para pelaku usaha susu kental manis, merupakan salah satu bentuk yang bertentangan dengan beberapa peraturan yang telah ditetapkan dalam penyelenggaraan iklan yang baik dan benar serta dapat menjadi edukasi bagi masyarakat, sehingga nantinya tidak ada lagi masyarakat yang tersesat akan kegunaan suatu produk yang diperdagangkan, sering kali ditemukan iklan-iklan yang terlalu melebih-lebihkan kualitas suatu produknya walaupun kelebihan pada produk tersebut tidak nyata, sehingga diperlukannya suatu kegiatan bisnis yang sehat sehingga ketika iklan yang ditampilkan suatu produk tidak perlu melebih-lebihkan khasiat produk tersebut.

Karena iklan susu kental manis yang tidak sesuai dengan ketentuan karena mencantumkan bahwa produk susu kental manis berpengaruh terhadap gizi, 
Volume 2 Nomor 2, Desember 2019

E-ISSN : 2655-7347

protein, energi dan vitamin dengan label yang telah disetujui, sehingga Badan

Pengawas Obat dan Makanan memjatuhkan sanksi kepada produsen SKM harus menarik sementara produknya dari peredaran, sampai produsen SKM memperbaiki iklan dari produknya sesuai dengan ketentuan dan surat edaran mengenai SKM yang telah dikeluarkan oleh Kepala BPOM.

Pelanggaran dalam bentuk manipulasi iklan yang dilakukan oleh pelaku usaha susu kental manis, keluarnya surat edaran pun tidak diindahkannya karena dalam isi surat tersebut menyatakan bahwa iklan SKM harus ditarik penayangannya di dalam media apapun, karena isi surat tersebut menyatakan bahwa Badan Pengawas Obat dan Makanan telah memberikan sanksi kepada pelaku usaha susu kental manis dalam bentuk sanksi administrasi sesuai dengan Peraturan Pemerintah Nomor 69 Tahun 1999 Tentang Label dan Iklan Pangan. Sanksi administratif yang diberika berupa :

1. Surat teguran secara tertulis

2. Larangan mengedarkan iklan untuk

3. Mewajibkan pelaku usaha untuk menarik produknya di pasaran.

4. menambahkan ketentuan batasan penggunaan dalam kemasan.

Namun setelah keluarnya surat edaran BPOM RI, ternyata iklan SKM masih beredar di media elektronik, berdasarkan hasil pengawasan yang dilakukan oleh Koalisi Peduli Kesehatan Masyarakat (Kopmas) melaporkan bahwa pelaku usaha susu kental manis melanggar Peraturan BPOM Nomor 31 Tahun 2018 Tentang Label Pangan Olahan pasal 54 huruf W, pasal 67 huruf W dan X. Menurut Kopmas terdapat sejumlah pelanggaran yang masih dilakukan oleh pelaku usaha susu kental manis diantaranya tata cara promosi iklan televisi, terdapat adegan yang menampilkan visual anak mengonsumsi secara langsung susu kental manis dari kemasan, serta kampanye melalui media sosial. Padahal larangan tersebut sudah diperingatkan dalam surat edaran Badan Pengawas Obat dan Makanan.

Dengan adanya pelanggaran kembali yang dilakukan oleh para produsen SKM, penulis berangggapan sebaiknya pemerintah lebih memperhatikan hak-hak perlindungan konsumen, karena konsumen berhak mendapatkan perlindungan hukum dari upaya-upaya tindak kecurangan yang dilakukan oleh produsen yang 
Volume 2 Nomor 2, Desember 2019

E-ISSN : 2655-7347

tidak jujur, bertanggung jawab dan cenderung nakal. Selain itu pemerintah harus lebih tegas dalam penindakan dan pengawasan terhadap suatu aturan yang telah ditetapkan sehingga tidak ada lagi kecolongan akibat dari peredaran iklan yang memanipulasi masyarakat.

Perlindungan hukum adalah suatu perlindungan yang diberikan kepada subjek hukum sesuai dengan aturan hukum, baik itu bersifat preventif dan juga representif, secara tertulis maupun tidak tertulis. Dengan kata lain perlindungan hukum diartikan sebagai suatu gambaran tersendiri dari fungsi hukum, yang memiliki konsep pemberian suatu keadilan, kepastian, dan kemanfaatan bagi seluruh masyarakat.

Perlindungan hukum terhadap konsumen diatur dalam Undang-Undang Perlindungan Konsumen. Dalam UUPK diatur antara lain berupa hak dan kewajiban konsumen, hak dan kewajiban pelaku usaha, perbuatan yang dilarang pelaku usaha dan pengawasan pemerintah. Perlindungan hukum yang diatur dalam UUPK bertujuan untuk memberikan keseimbangan antara pelaku usaha dan konsumen. Seperti yang diketahui dalam kegiatan bisnis tidak selamanya kedudukan konsumen dan pelaku usaha selalu berimbang sering kali menempatkan konsumen dalam posisi terlemah. Salah satunya melalui iklan yang ditampilkan oleh pelaku usaha untuk memasarkan produknya, tanpa memperhatikan hak-hak konsumen yang diatur dalam Pasal 4 Undang-Undang Perlindungan Konsumen.

Selain menjadi hak konsumen hal tersebut merupakan bentuk dari kewajiban pelaku usaha yang telah diatur dalam Pasal huruf (b) UUPK yang mewajibkan pelaku usaha mencantumkan informasi yang jujur, benar dan jelas dan tanpa membuat konsumen mencari tahu tentang informasi produk yang ia pilih. Ketidak tersedian informasi yang memadai dari pelaku usaha merupakan salah satu jenis cacat informasi yang merugikan konsumen.

Larangan diberikan kepada produsen yang diatur dalam UUPK yang menyatakan sebagai perbuatan melanggar hukum. Menurut Nurmadjito tujuan dari peraturan ini adalah untuk menertibkan perdangangan dan menciptakan iklim usaha yang sehat. Ketertiban tersebut sebagai salah satu bentuk perlindungan 
Volume 2 Nomor 2, Desember 2019

E-ISSN : 2655-7347

konsumen, adanya larangan tersebut untuk memastikan bahwa produk yang diperdangankan dalam masyarakat dilakukan dengan cara tidak melanggar hukum. Seperti praktik menyesatkan pada saat penawaran, promosi, mengiklankan, dan mengedarkan produk barang dan/atau jasa palsu. Suatu iklan dapat di edarkan melalui media teknologi, hal tersebut berkaitan dengan UndangUndang Penyiaran. Memberi tahu pembeli untuk membeli dan mempergunakan produk tersebut. Pada Pasal 46 ayat 3 UU Penyiaran.

Berdasarkan batasan materi iklan niaga sebagaimana yang tertera diatas, Undang-Undang Penyiaran memang secara eksplisit menyebutkan adanya manipulasi iklan sebagai suatu ketentuan. Tetapi dengan melihat dampak dari manipulasi iklan yang merugikan masyarakat sebagai konsumen, maka hal-hal tersebut dapat digolongkan sebagai perbuatan yang bertentangan dalam nilai-nilai kesusilaan dalam masyarakat. Kejujuran dan kebenaran dalam menyampaikan suatu inormasi sangat dijunjung tinggi dan penting dalam kehidupan sosial masyarakat.

Selain itu Undang-Undang Pangan juga turut mengatur perlindungan terhadap konsumen atas etika dalam beriklan. Hal tersebut diatur pada Pasal 104 Undang-Undang Pangan yaitu setiap iklan pangan yang diperdangangkan harus memuat pernyataan mengenai pangan dengan benar dan tidak menyesatkan. Begitupun dengan Pasal 105 ayat (2) yang menyatakan bahwa setiap orang yang menyatakan dalam iklan bahwa pangan yang diperdagangkan sesuai dengan klaim tertentu wajib bertanggung jawab atas kebenaran klaim tersebut.

Pada PP No 69 Tahun 99 juga terdapat perlindungan konsumen ketika mengiklankan. Hal tersebut diatur dalam PP No 69 Tahun 1999 yang tertuai dalam Pasal 14 yaitu setiap iklan tentang pangan yang diperdangankan wajib memuat keterangan mengenai pangan secara benar dan tidak menyesatkan, baik dalam bentuk gambar dan/atau suara, pernyataan dan/atau bentuk apapun lainnya.

Berdasarkan beberapa peraturan di atas jelas diatur bahwa setiap iklan yang beredar dalam masyarakat seharusnya memuat informasi secara jujur, benar dan jelas dan tidak memanipulasi iklan sehingga menyesatkan konsumen dalam menentukan pilihannya tanpa harus dirugikan. Melihat akibat dari efek negatif 
Volume 2 Nomor 2, Desember 2019

E-ISSN : 2655-7347

yang muncul di negeri ini dikarenakan tergoda akan tampilan iklan manipulatif yang ditampilkan oleh pelaku usaha, sedangkan terkadang tidak selamanya iklan tersebut membuat informasi yang benar dan jujur, karena pada umunya pelaku usaha selalu melebih-lebihkan produknya, serta meniadakan kelemahan produk tersebut.

Lebih lanjut, Undang-Undang Perlindungan Konsumen selain dalam memberikan perlindungan hukum terhadap konsumen akibat manipulasi iklan yang dilakukan oleh pelaku usaha mengatur pula tentang peran pemerintah terkait dengan produk beredar dalam masyarakat, hal ini diatur dalam UUPK Pasal 29 ayat (1).

Perlindungan hukum bagi konsumen lahir karena adanya hubungan hukum yang dilakukan oleh konsumen dan pelaku usaha yang menyebabkan suatu perselisihan atau sengketa. Dalam Undang-Undang Perlindungan Konsumen mengatur tentang penyelesaian sengketa yang dapat ditempuh melalui pengadilan atau di luar pengadilan berdasarkan pilihan para pihak yang bersangkutan:

1. Melalui Pengadilan

Penyelesaian sengketa yang menjadi acuan dalam dunia bisnis adalah penyelesaian sengketa yang berlangsung secara murah dan cepat, berbeda jika menempuh jalur pengadilan. Disamping itu, hasil dari putusan pengadilan belum tentu dapat menyelesaikan suatu masalah, karena tujuannya penyelesaian suatu sengketa diharapkan tidak memecah kontrak antara penjual dan pembeli. Hal ini urung terjadi jika dilakukan melalui mekanisme pengadilan, karena putusan akhir dari pengadilan akan berakhir dengan kekalahan pihak satu dan memenangkan pihak lainnya.

2. Di Luar Pengadilan

Penyelesaian sengketa konsumen yang dilakukan di luar pengadilan sesuai dengan UUPK Pasal 47. Penyelesaian sengketa yang dilakukan di luar mekanisme pengadilan itu sendiri tidak menghilangkan tanggung jawab pidana yang telah diatur oleh undang-undang.Upaya perlindungan hukum yang bersiat represif dilakukan setelah terjadinya suatu sengketa ataupun 
Volume 2 Nomor 2, Desember 2019

E-ISSN : 2655-7347

pelanggaran yang telah dilakukan, dalam hal ini dapat berupa diberikannya sanksi kepada pelaku usaha periklanan yang melanggar etika pariwara periklanan. Dalam Undang-Undang Perlindungan Konsumen terdapat setidaknya dua sanksi, yaitu sanksi administratif dan sanksi pidana.

\section{PENUTUP}

\section{A. Kesimpulan}

Berdasarkan hasil dari bab-bab sebelumnya dalam tugas akhir skripsi ini, maka selanjutnya penulis akan menarik kesimpulan, sebagai berikut:

Konsumen tentu saja membutuhkan sebuah perlindungan hukum untuk melindungi hak-haknya dan terhindar dari tipu daya yang dilakukan oleh pelaku usaha. Perlindungan hukum sendiri dibagi menjadi 2 (dua) yaitu perlindungan hukum preventif dan perlindungan hukum represif. Namun di Indonesia perlindungan hukum diberikan ketika sudah terjadi suatu pelanggaran. Perlindungan hukum bagi konsumen terhadap manipulasi iklan susu kental manis yang dilakukan pelaku usaha yang beredar di masyarakat, dalam praktiknya belum sesuai dengan apa yang telah diatur di dalam Undang-Undang Nomor 8 Tahun 1999 Tentang Perlindungan Konsumen, Peraturan Kepala Badan Pengawas Obat dan Makanan Republik Indonesia Nomor 2 Tahun 2016 Tentang Pedoman Teknis Pengawasan Periklanan Pangan Olahan dan Peraturan Pemerintah Republik Indonesia Nomor 69 Tahun 1999 Tentang Label dan Iklan Pangan. Walaupun peraturannya sudah ada, namun praktik penerapannya masih kurang dilaksanakan. Badan Pengawas Obat dan Makanan terrlihat masih sangat lalai kinerjanya dalam mengawasi produk dan iklan dari pelaku usaha, contohnya susu kental manis ini. Seperti yang diketahui bahwa produk susu kental manis ini sudah lama peredarannya di Indonesia dan sudah tidak asing lagi penggunannya sebagai sarapan tambahan bagi keluarga, ketika diteliti lebih lanjut ternyata iklan dan kandungan yang tercantum dalam susu kental manis tidak sesuai dan informasi yang menyesatkan bagi masyarakat khususnya konsumen susu kental manis. Padahal lahirnya Undang-Undang Perlindungan Konsumen 
Volume 2 Nomor 2, Desember 2019

E-ISSN : 2655-7347

diharapkan dapat menjadi sebuah acuan dalam memberikan perlindungan hukum terhadap konsumen, dan undang-undang tersebut sudah mengatur dengan jelas ketentuan-ketentuan yang dilanggar oleh para pelaku usaha susu kental manis, namun masih ada saja pelaku usaha yang melakukan tindakan "kotor" demi mempromosikan dan memperdagangkan prroduknya agar tetap laku dalam masyarakat. Walaupun BPOM sudah melakukan upaya perlindungan hukum secara represif dengan mengeluarkan surat edaran tekait susu kental manis, memberikan sanksi administratif kepada para pelaku usaha, dengan mewajibkan pelaku usaha menarik produk dan iklannya, namun dalam pelaksanaannya dirasa kurang optimal dan maksimal, karena masih ada konsumen yang tidak mengetahui tentang permasalahan susu kental manis tersebut.

\section{B. Saran}

1. Untuk Pelaku usaha, seharusnya menjalankan apa yang tertuai dalam UUPK. Karena kelangsungan usahanya bergantung kepada konsumen sebagai penerima dan pembeli dagangan yang diperdagangkan oleh penjual maka mereka berkewajiban menghasilkan suatu dagangan yang baik dan benar kemanfaatannya kepada konsumen. Jangan menggunakan hal-hal yang dilarang seperti manipulasi iklan, kandungan yang tidak sesuai dan informasi yang tidak sesuai akan kebenarannya.

2. Untuk pemerintah lebih khususnya kepada BPOM harus strong pengawasannya terhadap suatu iklan pelaku usaha dan produk yang diperdagangkan oleh pedagang apakah sudah memenuhi persyaratan. Dan menciptakan keseimbangan antara pelaku usaha dan konsumen agar terciptanya perlindugan hukum sesuai dengan UUPK. Ketika BPOM menemukan produk yang tidak sesuai dengan ketentuan dan peraturan maka jangan hanya mengeluarkan surat edaran ataupun pernyataan saja, tetapi harus mengsosialisasikan dan memberikan kepada masyarakat secara langsung. 
Volume 2 Nomor 2, Desember 2019

E-ISSN : 2655-7347

3. Untuk Konsumen, harus lebih teliti dan cerdas dalam memberi suatu barang dan/atau jasa apalagi jika barang tersebut berbentuk makanan dan minuman yang tujuannya untuk dikonsumsi, maka harus diteliti terlebih dahulu apakah kandungan yang terdapat didalamnya tercantum sama persis BPOM. Dan jika ada yang tidak sesuai seperti kasus susu kental manis diharapkan masyarakat melapor kepada BPOM agar ditindak lanjuti kebenarannya.

\section{DAFTAR PUSTAKA}

\section{A. BUKU}

Amiruddin dan H. Zainal Asikin. (20. Pengantar Metode Penelitian Hukum, Cetakan ke-1. (Jakarta: PT Raja Grafindo Persada,2004)

Hadjon, Philipus M. Perlindungan Hukum bagi Rakyat Indonesia. (Surabaya: Bina ilmu,1987)

Nazir, Moh. "Metode Penelitian”. (Bogor: Ghalia Indonesia,2005).

Peter, Mahmud. Penelitian Hukum, Cetakan ke-7. (Jakarta: Kencana Prenada Media Group,2016).

Soekanto, Soerjono dan Sri Mamudji. Penelitian Hukum Normatif, (Jakarta: Raja Grafindo Persad,2006)

\section{B. Peraturan Perundang-Undangan}

Indonesia, Undang-undang Nomor 8 Tahun 1999 tentang Perlindungan Konsumen (Lembaran Negara Republik Indonesia Tahun 1999 Nomor 22, Tambahan Lembaran Negara Republik Indonesia Nomor 3821). 